\title{
Judicial Review in an Age of Hyper-Polarization and Alternative Facts
}

\author{
DAVID A. DANA* \\ MICHAEL BARSA**
}

TABLE OF CONTENTS

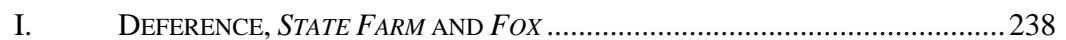

II. THE CASE OF FUEL ECONOMY STANDARDS .............................................2 248

A. Factual and Legal Background.......................................................248

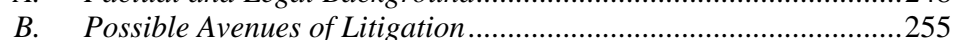

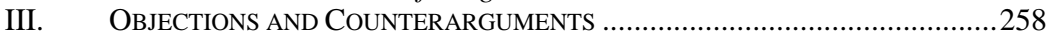

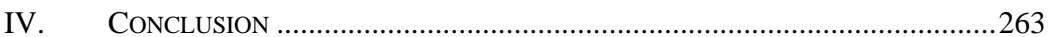

"'I have been consistently informed by multiple career people at E.P.A. that Administrator Pruitt is not meeting with them ahead of making decisions like rolling back these major regulations,' said James J. Jones, who had worked at the agency since the Reagan administration before retiring in January.... Instead, Mr. Pruitt has outsourced crucial work to a network of lawyers, lobbyists and other allies ...."1

* (C) 2018 David A. Dana. Kirkland \& Ellis Professor of Law, Northwestern University Pritzker School of Law.

** (C) 2018 Michael Barsa. Professor of Practice, Northwestern University Pritzker School of Law.

1. Coral Davenport, Counseled by Industry, Not Staff, E.P.A. Chief is Off to a Blazing Start, N.Y. TIMES (July 1, 2017), https://www.nytimes.com/2017/07/01/us/politics/ trump-epa-chief-pruitt-regulations-climate-change.html [https://perma.cc/47NJ-8RAB]. 
U.S. EPA Administrator Scott Pruitt is leading a formal initiative to challenge mainstream climate science using a "back-and-forth critique" by governmentrecruited experts, according to a senior administration official. ... Climate scientists express concern that the "red team, blue team" concept could politicize scientific research and disproportionately elevate the views of a relatively small number of experts who disagree with mainstream scientists. ${ }^{2}$

"[The] Trump administration is in [an] unending battle for 'deconstruction of the administrative state[.]",3

We live in an age of hyper-polarization in the United States, in which Democrats and Republicans increasingly lack common ground as to what the government should or should not do. ${ }^{4}$ Moreover, partisan disagreement is not limited to values, but also directly implicates facts. Republicans and Democrats increasingly have different understandings of the underlying facts that are relevant to government policies. ${ }^{5}$

The pattern of polarization is not symmetric, however. One recent study suggests that while the views of Democrats in social media have moved somewhat to the left, the views of Republicans in social media have shifted

2. Emily Holden, Pruitt Will Launch Program to 'Critique’ Climate Science, E\&E NEws (June 30, 2017), https://www.eenews.net/stories/1060056858 [https://perma.cc/ REU7-W86C].

3. Philip Rucker, Bannon: Trump Administration is in Unending Battle for 'Deconstruction of the Administrative State', WASH. Post (Feb. 23, 2017), https://www. washingtonpost.com/news/powerpost/wp/2017/02/23/bannon-trump-administration-isin-unending-battle-for-deconstruction-of-the-administrative-state/?utm_term=.33311b72fe96 [https://perma.cc/3B4S-47LH] (quoting Bannon).

4. See, e.g., Alan I. Abramowitz \& Kyle L. Saunders, Is Polarization a Myth?, 70 J. OF PoL. 542, 542-54 (2008) (finding substantial evidence of polarization); see also Political Polarization in the American Public, Pew Res. CTR. (June 12, 2014), http://www.peoplepress.org/2014/06/12/political-polarization-in-the-american-public/ [https://perma.cc/2BCSGAEC]; Alexander George Theodoridis, The Hyper-Polarization of America, ScI. Am. (Nov. 7, 2016), https://blogs.scientificamerican.com/guest-blog/the-hyper-polarization-of-america/ [https://perma.cc/T5EA-LFSS]; Anthony J. Gaughan, Illiberal Democracy: The Toxic Mix of Fake News, Hyperpolarization, and Partisan Election Administration, 12 DUKE J. CONST. L. \& PuB. POL'y 57, 59-61 (2017).

5. See Donald Braman, Dan M. Kahan, Ellen Peters, Maggie Wittlin \& Paul Slovic, The Polarizing Impact of Science Literacy and Numeracy on Perceived Climate Change Risks, NATURE Climate CHANGE, May 27, 2012, at 1, 2, 4-5, http://www.nature. com/nclimate/journal/v2/n10/full/nclimate1547.html?foxtrotcallback=true [https://perma.cc/ F5N5-LNMY] (the Democratic/Republican split on facts mirrors the divides that Dan Kahan and other researchers have discovered using the framework of cultural cognition, in which the relevant categories include hierarchalists/authoritarians and egalitarians/communitarians); see also Olga Khazan, How to Overcome Political Irrationality About Facts, THE ATLANTIC (Jan. 26, 2017), https://www.theatlantic.com/science/archive/2017/01/how-curiosity-burstsour-political-bubbles/514451/ [https://perma.cc/YB8M-WLAN] (discussing intense polarization as to facts and possible means to reduce it). 
very far to the right. ${ }^{6}$ Moreover, within the Republican party-especially its ascendant conservative wing-facts that are rooted in well-established science, that can be verified using scientific method, are increasingly disregarded in favor of what a leading Republican spokesman famously defended as "alternative facts." 7 The degradation of factual discourse does not seem to be a transitory phenomenon. Rather, it appears to be a reflection of contemporary features of American life, including the prevalence of social media, income inequality, and residential geographic segregation by class, political affiliations, and social background. ${ }^{8}$

This hyper-polarization and tendency to embrace "alternative facts" on one end of the political spectrum has implications for judicial review of administrative agencies. A principal rationale for deferential judicial review is that agencies are technocratic experts. Courts, as non-experts, defer to agencies in part because they trust the integrity of agencies' technical analyses and judgment. But in an age of hyper-polarization, deference based on agencies' technical competence is less justified. Courts cannot now readily assume that agencies' technical, expert, "factual" analyses and conclusions are well-supported. Deference based on technocratic expertise is particularly questionable when an agency shifts its position after an election by rejecting the previous administration's policy and adopting a dramatically different one. Such policy swings typically occur around focal points of partisan

6. Yochai Benkler, Robert Faris, Hal Roberts \& Ethan Zuckerman, Study: BreitbartLed Right-Wing Media Ecosystem Altered Broader Media Agenda, ColumBIA Journalism REV. (Mar. 3, 2017), www.cjr.org/analysis/breitbart-media-trump-harvard-study.php [https://perma.cc/GG9C-DDT5]; see also Thomas E. Mann \& Norman J. Ornstein, How the Republicans Broke Congress, N.Y. TIMEs (Dec. 2, 2017), www.nytimes.com/2017/12/ 02/opinion/sunday/republicans-broke-congress-politics.html?_r=0 [https://perma.cc/T48KAVFM] (explaining that the Republican Party has moved farther from a "truth" based approach to governance than the Democratic Party, to the nation's detriment).

7. See Conway: Press Secretary Gave 'Alternative Facts', NBCNEWS.COM (Jan. 22, 2017), https://www.nbcnews.com/meet-the-press/video/conway-press-secretary-gavealternative-facts-860142147643 [https://perma.cc/CT3Q-TVCU (depicting White House senior advisor Kellyanne Conway as saying: "You're saying it’s a falsehood ... our press secretary gave alternative facts to that.”).

8. For discussions of the role of these factors in creating polarization, see CAss R. Sunstein, \#Republic: Divided Democracy in the Age of Social Media 76-85 (2017); John V. Duca and Jason L. Saving, Income Inequality and Political Polarization: Time Series Evidence Over Nine Decades, FEDERAL RESERVE BANK OF DALlas 464-65 (2016), https:// www.dallasfed.org/assets/documents/research/papers/2014/wp1408.pdf [https://perma.cc/ APC5-E299]; Ian Chipman, Political Polarization's Geographic Roots Run Deep, STANDARD Bus. (May 2, 2017), https://www.gsb.stanford.edu/insights/political-polarizationsgeographic-roots-run-deep [https://perma.cc/HLT9-AY97]. 
hyper-polarization-it is with respect to such focal point issues that the assumption of technocratic competence is least tenable. ${ }^{9}$

Building on this insight about the effects of hyper-polarization, we argue for a re-assessment of how courts review administrative agency changes in policy. ${ }^{10}$ While some precedent suggests that agencies face an especially "hard look" when they deviate from past practices or approaches, the United States Supreme Court's decision in FCC v. Fox Television Stations, Inc. ${ }^{11}$ is generally read as establishing the same level of deferential review when an agency shifts course as when it stays the course or addresses an issue for the very first time. ${ }^{12}$ And, as a normative matter, scholars have argued for deferential review regarding agency shifts so as to avoid agency "ossification" and bureaucratic inertia, and so as to give effect to the values of the party that just won power because, in a democracy, elections must matter. ${ }^{13}$

9. See Anne Joseph O’Connell, Agency Rulemaking and Political Transitions, 105 Nw. U. L. REV. 56-57 (2011), https://scholarlycommons.law.northwestern.edu/cgi/view content.cgi?referer=https:/www.google.com/\&httpsredir=1\&article=1166\&context=nulr (“... the timing of an agency decision-for instance, the completion of a regulation right before a president leaves office or a withdrawal of a proposed rule immediately after a new president comes into office-may suggest that the action is "arbitrary and capricious" under the APA" in that the timing reflects political imperatives, rather than technocratic ones). See Nick Rowley, Australia's Climate Policy is Messier than a Teenager's Bedroom, but is Turnbull the Man to Tidy it Up?, THE CONVERSATION (Oct. 8, 2015), https://theconversation. com/australias-climate-policy-is-messier-than-a-teenagers-bedroom-but-is-turnbull-theman-to-tidy-it-up-48809 [https://perma.cc/T6HY-HN7F]; see also Helena Afonso (Associate Economic Affairs Officer, UN/DESA), et al., UN-DESA Policy Brief \#48: Adaptation to Climate Change Requires Transformative Policies (Sept. 2016) (arguing that effective climate adaptation requires coherent, long-term strategies), https://www.un.org/development/desa/dpad/ wp-content/uploads/sites/45/post/WESS2016-PB5.pdf [https://perma.cc/9MUN-VVLA].

10. Allison Orr Larsen makes a similar argument, but focused not on review of agency action but rather on constitutional review of legislation premised on purported facts. See Allison Orr Larsen, Constitutional Law in an Age of Alternative Facts, 93 N.Y.U. L. REV. 175 (2018), https://papers.ssrn.com/sol3/papers.cfm?abstract_id=303303 [https://perma.cc/ W8DK-QPDA].

11. FCC v. Fox TV Stations, Inc., 556 U.S. 502 (2009).

12. See, e.g., Ronald Levin, Hard Look Review, Policy Change, and Fox Television, 65 U. Miami L. REV. 555, 573 (2011) (“The Court's position on the issue comes down to this: Unless reliance interests or inconsistent readings of a factual record are involved, open acknowledgment of the change and a defense of the new policy on its own terms should ordinarily suffice.”), https://repository.law.miami.edu/cgi/viewcontent.cgi?referer= https://www.google.com/\&httpsredir=1\&article=1159\&context=umlr [https://perma.cc/ G4BG-QTW2].

13. See id. (arguing that Fox appropriately allows agencies the room they need to reflect the change in values of the incoming or new Administration); Randy J. Kozel \& Jeffrey A. Pojaniowski, Administrative Change, 59 UCLA L. REV. 112, 132 (2011) ("One common approach has been to read Chevron as cutting against heightened review of administrative change: Agency positions are not 'carved in stone,' and Chevron's assumption of capacious administrative discretion to interpret statutes applies to revisions just as it does to initial rulings.”), http://scholarship.law.nd.edu/cgi/viewcontent.cgi?article 
Nonetheless, we believe that Fox need not—and should not—-be read to preclude courts from adopting the kind of judicial review our age of hyperpolarization justifies. In particular, Fox supports courts holding agencies to a high standard in explaining why the facts that a previous administration relied upon are no longer true or relevant or no longer weigh heavily in favor of conclusions reached by the previous administration. Notably, nothing in Fox prevents courts from either seriously questioning an agency about what new facts support its recent policy change, or from interrogating the basis for those newly claimed facts. A broad but fair reading of Fox also supports courts calling on agencies to meaningfully explain how their shifts will affect reliance interests, broadly understood, and how the agencies sought, if they did, to meaningfully take account of those reliance interests. We seek here to rebut recent claims that current case law allows an agency almost unlimited discretion to discard the rules adopted during a previous presidential administration. ${ }^{14}$

Hyper-polarization also has implications beyond the courts in the drafting of legislation and regulation. In particular, the drafters of legislation and regulation face a dilemma when they seek to fashion a provision that allows or requires implementing agencies to periodically review their own regulations and to determine their continuing appropriateness. On the one hand, such provisions seem sensible as tools to address problems of bureaucratic

\footnotetext{
=1447\&context=law_faculty_scholarship [http://perma.cc/C5DS-QQ2B]; Miriam Seifter, Judicial Review of Agency Change, 127 HARV. L. REV. 2070, 2091 (2014) ("This Note suggests that the standard should be deferential and accept rational agency attempts to reconcile their precedents. Courts may need to adapt this general standard to suit particular regulatory contexts.”), http://harvardlawreview.org/wp-content/uploads/2014/05/vol127_judicial_review_of_agency_ change.pdf [https://perma.cc/; but see David H. Becker, Changing Direction in Administrative Agency Rulemaking: "Reasoned Analysis," The Roadless Rule Repeal, and the 2006 National Park Service Management Policies, 30 ENVIRONS. ENVTL. L. \& POL’y 65 (Fall 2006) (arguing, pre Fox, that agencies do and should use State Farm to scrutinize agency shifts in policy), https://environs.law.ucdavis.edu/volumes/30/1/becker.pdf [https://perma.cc/Z4FD-P4B4]; see also infra note 25 (discussing the agency ossification debate). For her part, Short sees Fox as representing a possible shift toward allowing political-reason-giving as a basis of agency action and thus allowing the agency to in effect enjoy broader deference, but it is unclear if she sees Fox as changing the review applicable to all agency action or only the review applicable to agency shifts in position; see Jodi L. Short, The Political Turn in American Administrative Law: Power, Rationality, and Reasons, 61 DukE L.J. 1811, 1829 (2012), https://scholarship.law.duke.edu/cgi/viewcontent.cgi?referer=https://www.google.com/\& httpsredir=1\&article=1540\&context=dlj [https://perma.cc/VU6G-PNL5].

14. See infra note 110 (discussing the Trump Administration's reliance on the idea that agencies have an inherent power to reconsider and set aside rules adopted by a previous administration).
} 
inertia and as means to encourage agencies to flexibly respond to new information and circumstances. From a technocratic, "good government," non-polarized-politics, idealized-public-interest perspective, the case is clear for requiring periodic agency review and encouraging agencies to adapt policy to altered circumstances. The Supreme Court itself, in a less polarized era, acknowledged as much. ${ }^{15}$ On the other hand, in an age of hyperpolarization, such flexibility-enhancing provisions can be invitations to the wholesale, immediate undoing of regulations without meaningful process or analysis by a new administration that represents a different political party than its predecessor.

The effectiveness of judicial review in an age of hyper-polarization depends in part on whether flexibility-enhancing provisions in statutes and regulations formally require agencies to make factual determinations as part of their process for determining whether to alter current policies. Such specific factfinding requirements allow — and indeed push—judges to require agencies to assemble meaningful factual records before dramatically shifting policy. If such fact-finding requirements are written into law and enforced by courts, there is a greater likelihood that, even in an era of hyper-polarization, technical competence grounded in data and scientific method will be a major driver of agency behavior over time.

We develop our argument about judicial review and legislative and regulatory drafting in an age of hyper-polarization in the context of a contemporary agency controversy - the Trump EPA's effort to re-open and perhaps roll back mileage fuel economy standards adopted and then reviewed and reapproved by the Obama EPA. The Trump EPA's effort has not yet reached the courts, so we offer a roadmap of how courts might evaluate that effort and the justifications for different approaches. We also use the case study to illustrate how regulation drafters, if they aspire to ensure a continuous practice of fact-based decisionmaking, should tie provisions for regulatory flexibility to formal fact-finding requirements that the agency must satisfy. For the fuel economy standards, the review provision in the applicable regulation, while unobjectionable enough on its face, was not well-advised from the perspective of ensuring continuity in fact-based decisionmaking. ${ }^{16}$

This Article is organized as follows: Part I reviews the case law and commentary on judicial review of agency shifts in policy or practice, focusing on the technocratic case for deference and how recent political realities

15. See, e.g., American Trucking Associations, Inc., et al. v. Atchison, Topeka \& Santa Fe RR Co., et al., 387 U.S. 397, 416 (1967) ("Regulatory agencies do not establish rules of conduct to last forever; they are supposed . . . to adapt their rules and practices to the Nation's needs in a volatile, changing economy. They are neither required nor supposed to regulate the present and the future within the inflexible limits of yesterday.”).

16. See infra notes 88-90. 
call such deference into question. Part II sets forth the background and history regarding fuel economy standards, leading to the Obama Administration's adoption of standards in 2012 and the "midterm" review of those standards that Obama's EPA declared final as of January 2017. Part II also reviews the legal issues surrounding Trump's EPA's "re-opening” of the midterm review. We suggest how courts could, and should, consider any forthcoming dilution in the standards proposed by EPA. Part III takes up objections to our call for a less deferential judicial posture and, in particular, considers the objection that judges themselves may be hyper-polarized. Part III also considers whether judges simply lack the capacity to ferret out the difference between "alternative facts" and actual facts.

We readily acknowledge that judicial detachment and competencies have limits but maintain that, overall, we all will be better off if judges take a genuinely hard look at agency policy shifts and thereby encourage agencies to operate in the shadow of such scrutiny. Such review could prompt agencies to ground their policy shifts in a considered account of why the available facts better support a new policy rather than the previous one and, if they cannot do that, to forego policy shifts. Alternatively, such review could lead agencies to disclaim a factual basis for their policy shifts and instead explain those shifts in terms of their values and ideology, inviting the courts to decide whether those values and ideology are permissible bases for changing policy under substantive statutes and the Administrative Procedure Act. ${ }^{17}$ We think either of these effects would be preferable to judicial rubber-stamping of agency decisions that are purportedly based

17. We recognize that there are many potential problems in encouraging agencies to justify policy shifts in terms of changed values or ideology. For one thing, some ideology (for example, an ideology that views the poor as non-earners whose needs government affirmatively should disregard a la Ayn Rand) should be deemed irrational or arbitrary under the APA, and almost certainly would be by any court, yet that ideology really might be at work in proposals to reduce social welfare benefits. Because agencies would not want to offer values or ideology motivations that would generate negative publicity and/or lead a court to find a violation of the APA or a substantive statute, they might offer the courts "fake" but seemingly innocuous values or ideology rationales or ones that are so vague that they afford no opportunity for meaningful judicial review. See Short, supra note 13, at 1853-56. Short also suggests, without necessarily endorsing the position, that requiring agencies to offer factual or technical reasons for their actions fosters public dialogue more than allowing them to rely on political reason-giving. Id. at 1823 ("Finally, reason giving legitimates the exercise of administrative power. Civic republicans and others partial to deliberative-democratic models of agency legitimacy see reasons as a mechanism for facilitating dialogue toward the end of generating public consensus around policy outcomes.”). 
on factual or technical criteria but in reality lack factual or technical justification.

\section{DEFERENCE, STATE FARM AND FOX}

Why should courts defer to the decisions of agencies? This is a foundational question for any discussion of judicial review of agency action. The leading modern precedent on deference, Chevron $v . E P A,{ }^{18}$ articulates two rationales that dominate academic discourse-political accountability and technical expertise. The first rationale resonates in political theory: agencies - at least non-independent agencies - are more politically accountable than Article III courts, to the extent they reflect the politics of the presidential administration in power. Hence, it is appropriate that agencies have discretion to act where the statutory directives to the agency are ambiguous. ${ }^{19}$

This political rationale is arguably problematic insofar as it undercuts the role of Congress in directing agencies through legislation. Moreover, agencies generally do not invoke the political rationale in explaining their shifts in position.

Instead, agencies frame shifts in terms of changing data and circumstances in the world (including sometimes new statutes and precedents). ${ }^{20}$ In other words, agencies tend to rely on technocratic arguments in justifying their shifts in position — and little wonder, because superior technical expertise is a virtually uncontested reason for judicial deference. Moreover, legislation is sometimes structured so as to require that an agency make a determination

18. Chevron, U.S.A., Inc. v. Nat. RES. Def. Council, Inc., 467 U.S. 837 (1984).

19. Id. at 865; see also Anne Joseph O’Connell, Agency Rulemaking and Political Transitions, 105 Nw. U. L. REV. 471, 473 (2011) (“At the most general level, courts tend to use one of two theories of agencies to justify deference to agency decisions ... political accountability... [and] expertise"). This democratic-theory argument has proponents, notably Elena Kagan, at least before she joined the Court, see Elena Kagan, Presidential Administration, 114 HARV. L. REV. 2245, 2384 (2001) ("Presidential administration . . advances political accountability by subjecting the bureaucracy to the control mechanism most open to public examination and most responsive to public opinion.”), but also notable detractors, especially since the election of Donald Trump. See e.g., Daniel Farber, Presidential Administration Under Trump, U.C. Berkeley Pub. L. ReS. PAPERS (Aug. 9, 2017), https://papers.ssrn.com/sol3/papers.cfm?abstract_id=3015591 [https://perma.cc/ P2X8-MXP5].

20. See Kathryn A. Watts, Proposing A Place for Politics in Arbitrary and Capricious Review, 119 YALE L.J. 2 (2009) ("agencies today tend to sweep political influences under the rug even when such influences offer the most rational explanation for the action.”). Arguably,_Motor Vehicle Mfrs. Ass'n of U.S., Inc. v. State Farm Mut. Auto. Ins. Co., 463 U.S. 29 (1983), encouraged agencies to justify their actions in rationalistic, technocratic, evidence-based terms, rather than relying on political or political accountability reasons. See Short, supra note 13, at 1820 ("State Farm adopted the "“rationalist" model of reason giving' in which the onus on the agency is 'to compile evidence supporting [its] reasons' and 'consider, analyze, and reject contrary evidence'”). 
that implicates some technocratic expertise, such as the Clean Air Act requirement that EPA make a finding as to whether a pollutant endangers public health or welfare. ${ }^{21}$

The more technocratic or scientific the question upon which an agency has taken a position, the more exuberantly courts proclaim the need for deference. The Supreme Court's statement in Baltimore Gas is typical: "When the agency 'is making predictions, within its area of special expertise, at the frontiers of science ... a reviewing court must generally be at its most deferential.",22 The Ninth Circuit also recently articulated this view: "Deference to the informed discretion of the responsible Federal Agencies is especially important, where, as here, the agency's decision involves a high level of technical expertise.”23

Unsurprisingly, the Trump Administration is trumpeting the deferenceto-technical-expertise argument in seeking to undo Obama Administration policies. One example is EPA's recent decision to partially stay a June 2016 Clean Air Act rule regarding methane omissions from oil and gas extraction facilities. Methane is a powerful greenhouse gas and thus a contributor to climate change; methane emissions in oil and gas drilling also are associated with the release of certain toxic chemicals. ${ }^{24}$ In arguing to the DC Circuit that EPA did not need to engage in a new rulemaking in order to stay and reconsider the methane rule, the Trump Administration did not invoke a conception of procedural autonomy for an agency, nor did it rest its case on the legitimacy of a shift in political values between

21. See 42 U.S.C.A. § 7521(a)(1) (“The Administrator shall by regulation prescribe (and from time to time revise) in accordance with the provisions of this section, standards applicable to the emission of any air pollutant from any class or classes of new motor vehicles or new motor vehicle engines, which in his judgment cause, or contribute to, air pollution which may reasonably be anticipated to endanger public health or welfare.”).

22. Baltimore Gas \& Elec. Co. v. Nat. Res. Def. Council, Inc., 462 U.S. 87, 103 (1983).

23. Nat'l Wildlife Fed'n v. Nat'l Marine Fisheries Serv., 422 F.3d 782, 798 (9th Cir. 2005) (noting, however, that even in highly technical matters, deference to agencies is not unlimited, and citing Baltimore Gas \& Elec. Co., 462 U.S. at 103).

24. See generally, Methane Pollution from the Oil \& Gas Industry Harms Public Health, ENVTL. DEF. FUnD (last visited Jan. 17, 2017), https://www.edf.org/sites/default/ files/content/methane_rule_health_fact_sheet_reboot_final_no_citations.pdf [https:// perma.cc/7RWV-UGUA]; Gayathri Vaidyanathan, How Bad of a Greenhouse Gas is Methane?, ScI. AM. (Dec. 22, 2015), https://www.scientificamerican.com/article/howbad-of-a-greenhouse-gas-is-methane/ [https://perma.cc/L4XX-2XBH]; Phil McKenna, The EPA's Natural Gas Problem, PBS (Feb. 11, 2015), http://www.pbs.org/wgbh/nova/ next/earth/methane-regulations/ [https://perma.cc/9F66-7TS6]; Center for Biological Diversity, Natural Gas Fact Sheet (last visited Jan. 16, 2018), http://www.biologicaldiversity.org/programs/ climate_law_institute/pdfs/NaturalGasFactsheet.pdf [https://perma.cc/3MHK-7T3B]. 
the Obama and Trump Administrations with respect to the question of climate change. Instead, the Trump Administration argued deference to the technical expertise of the agency. In its brief, EPA emphasized that "courts are at their 'most deferential' when an agency evaluates scientific or technical matters," and argued that "[t]he questions presented here are factual in nature and fall with EPA's special expertise to assess the scientific and other issues in the comments it received and determine what issues were, could have, and could not have been raised." 25

Among academics, the most powerful recent defense of deferential review - including deferential review of agency shifts in positions-is Jacob Gerson's and Adrean Vermeule's Thin Rationality. The authors argue that courts engage in thin rationality review and should continue to so. ${ }^{26}$ Part of their argument is based on the idea that the gap in technical expertise between courts and administrative agencies is so great that agencies cannot fully explain their decisions. This discrepancy thus justifies the tendency by courts to require very little of the agencies, by way of explanation. The authors explain: " $[\mathrm{I}] \mathrm{n}$ many fields, experts have tacit knowledge that they cannot communicate, at least at acceptable cost, to generalist observers or other nonexperts. Tacit knowledge is how-to local knowledge.... Because such knowledge is ubiquitous, there is always a question whether those who can do something are able to explain how they do it. Those who can do often can't teach. ...”27 They also suggest that agencies are best at confronting questions of genuine uncertainty that are rife in policymaking and for which there are no purely objective, fact-based, certain answers. ${ }^{28}$

The problem with deference to either the implicit or explicit technical expertise of administrative agencies - and in particular extreme deference to agency judgments regarding questions involving technical and scientific complexity and uncertainty-is that it assumes that an agency is, in good

25. Respondent's Opposition to Petitioner's Emergency Motion for a Stay or, in the Alternative, Summary Vacatur, at 15-16, Clean Air Council v. EPA, No. 17-1145 (D.C. Cir. June 15, 2017).

26. Jacob Gersen \& Adriene Vermuele, Thin Rationality Review, 114 Mich. L. REV. 1355 (2016) (arguing for something like thin rationality review as a means to free up scarce agency resources and allow for more collaboration among agencies and stakeholders); see also Sidney A. Shapiro \& Richard W. Murphy, Arbitrariness Review Made Reasonable, 92 NotRe DAme L. REV. 331 (2016) (arguing that a less restrictive arbitrariness review would address the problem that judicial review imposes high costs on resource-constrained agencies); Thomas O. McGarity, Some Thoughts on "Deossifying” the Rulemaking Process, 41 DukE L.J. 1385 (1992) (same); Richard J. Pierce, Jr., Rulemaking Ossification Is Real: A Response to "Testing the Ossification Hypothesis," 80 GEO. WASH. L. REV. 1493 (2012) (same); Jody Freeman, Collaborative Governance in the Administrative State, 45 UCLA L. REV. 1, 9 n.19 (1997) (arguing that deferential judicial review is valuable as a means to facilitating collaborative governance).

27. Gersen \& Vermuele, supra note 26, at 1396.

28. Id. at 1359 . 
faith, exercising its expertise. Such deference assumes that agency expertise actually informs and constrains agency judgments, even if ideology also plays a role. But this assumption cannot carry as much weight as it might have in a different time. Now, we live in a hyper-polarized world where the previous administration's efforts must, by definition, be deemed wrong by the new administration and where accepted scientific methods and evidence-based approaches may not always be deemed superior to alternative facts. The case for highly deferential review loses some of its grounding when framed in the political world we inhabit today. In such a world, courts should have a larger role in reviewing the agency's factual analyses, notwithstanding judges' obvious disadvantages as non-expert generalists.

Does current law allow a court to engage in meaningful, searching review of agency shifts in policy? The answer is yes. As discussed below, State Farm $^{29}$ provides the clearest example of the Supreme Court calling on an agency to explain why the facts the agency previously relied upon no longer matter after an election brings a new party into power in the White House. State Farm is perhaps even more apt in today's polarized world than when it was decided. The Supreme Court decision in Fox seems to alter the State Farm standard for judicial review of agency shifts, but, read closely, Fox allows for essentially the same kind of review that the Court employed in State Farm. Moreover, a recent Supreme Court case that addressed Fox, Encino Motorcars, LLC v. Navarro, ${ }^{30}$ supports this reading of Fox.

State Farm involved a National Highway Traffic Safety Administration order requiring the installation of passive restraints (airbags or automatic seat belts) in cars. The rationale for the NHTSA requirement was, in large part, that passive restraints would save enough lives to justify the cost. The Reagan Administration's NHTSA withdrew the passive restraint order, explaining that, contrary to the Carter Administration's NHTSA, it believed automatic belts would save virtually no lives because people would simply leave them detached. However, the Reagan NHTSA developed no empirical evidence for this assumption. Moreover, the Reagan NHTSA did not even question the Carter NHTSA's finding that air bags are an effective life-saving device. The Court held NHTSA's course change arbitrary and capricious in an opinion often deemed a quintessential expression of the "hard look"

29. 463 U.S. $29(1983)$.
30. $\quad 136$ S. Ct. $2117,2125-26$ (2016). 
approach to judicial review of agency action. ${ }^{31}$ As the Court explained, "[e]xpert discretion is the lifeblood of the administrative process, but 'unless we make the requirements for administrative action strict and demanding, expertise, the strength of modern government, can become a monster which rules with no practical limits on its discretion.",32

Fox, decided in 2007, is a fractured decision that cannot be understood solely by reading the majority opinion. For many years, the FCC provided broadcasters a safe harbor against a finding of a violation for a single utterance of an otherwise prohibited swear word. ${ }^{33}$ In 2000, the Bush Administration FCC shifted course, using an enforcement action involving a Golden Globes broadcast to declare that even a single utterance of a swear word could subject a broadcaster to penalties. In its Golden Globes order, the FCC provided essentially empirical reasons to support its rescission of the safe-harbor policy and its new policy of citing broadcasters for fleeting expletives. The FCC argued that categorically exempting fleeting expletives from enforcement would encourage widespread use of offensive language by broadcasters, and in particular, would harm children, who would be forced to suffer the harmful "first blow" of fleeting profanities. ${ }^{34}$

Applying State Farm, the Second Circuit found the FCC shift in policy unreasoned because the agency did not explain why a single utterance was harmful, such that it justified imposing a burden on First Amendment expression, when for years the agency's policy assumed little or no harm. The Second Circuit also concluded that the agency failed to adequately explain its view that allowing single utterances would lead to an explosion

31. See State Farm, 463 U.S. at 43; see also Gerson \& Vermeule, supra note 26, at 1361 (State Farm may be mischaracterized as the touchstone for hard look review). The term hard look, however, predates State Farm and originated in a string of D.C. Circuit cases, which may or may not have engaged in the same kind of review as State Farm. See Short, supra note 13, at 1820 n.33; see also Pikes Peak Broad. Co. v. FCC, 422 F.2d 671, 682 (D.C. Cir. 1969); Greater Bos. Television Corp. v. FCC, 444 F.2d 841, 851 (D.C. Cir. 1970); Nat'l Lime Ass’n v. EPA, 627 F.2d 416, 451 n.126 (D.C. Cir. 1980).

32. State Farm, 463 U.S. at 48 (quoting New York v. United States, 342 U.S. 882, 884 (1951) (dissenting opinion)).

33. The safe harbor originally may have been adopted in part by the FCC in part to comply with the Supreme Court's ruling in FCC v. Pacifica, 438 U.S 726 (1978), in which the Court seemed to rule that the FCC may limit indecent speech, like swear words, but in doing so, must focus on the context in which the words are spoken to determine whether the public interest in preventing children from hearing such words outweighs the First Amendment concerns with limiting speech, albeit indecent speech. See id. at 742.

34. In re Complaints Against Various Broadcast Licensees Regarding Their Airing of the "Golden Globe Awards" Program, 19 FCC Rcd. 4975, 4976 (2004); see also Short, supra note 13, at 1825-26 (discussing FCC Golden Globes enforcement action and Fox). 
of profanity on television, despite the fact that single utterances had been allowed for many years. ${ }^{35}$

Writing for the majority, Justice Scalia implicitly rejected the Second Circuit's view that the FCC policy was based on a change in the view of the FCC as to the harm of single obscene utterances on viewers (especially children). Although the Second Circuit relied on the reasons the FCC itself had cited for the policy change, Justice Scalia explained that the agency shift simply reflected the correction of an agency misimpression that the Supreme Court's constitutional jurisprudence compelled a safe harbor for single utterances of obscenities. Facts in the world - the extralegal world, at least - do not figure in the majority opinion, which readily finds the FCC shift to be compliant with the APA. Justice Scalia also addressed the view that State Farm stands for the proposition that agency shifts in position warrant closer judicial review than other agency actions. That view is entirely incorrect, according to Justice Scalia:

The Second Circuit has interpreted the Administrative Procedure Act and our
opinion in State Farm as requiring agencies to make clear "“why the original
reasons for adopting the [displaced] rule or policy are no longer dispositive"” as
well as " "why the new rule effectuates the statute as well as or better than the old
rule.'” 489 F.3d, at $456-457$ (quoting New York Council, Assn. of Civilian Technicians
v. FLRA, 757 F.2d 502, 508 (C.A.2 1985) (emphasis deleted). The Court of Appeals
for the District of Columbia Circuit has similarly indicated that a court's standard
of review is "heightened somewhat” when an agency reverses course. NAACP v.
FCC, 682 F.2d 993, 998 (1982).... We find no basis in the Administrative Procedure
Act or in our opinions for a requirement that all agency change be subjected to
more searching review. The Act mentions no such heightened standard. And our
opinion in State Farm neither held nor implied that every agency action representing
a policy change must be justified by reasons more substantial than those required
to adopt a policy in the first instance. 36

While Justice Scalia's opinion for the majority states that there is the same kind of review for agency changes in position as there is for any other agency action, the opinion seems to concede that may not be so when the agency shift is based on a change in the agency's assessment of the relevant facts. Justice Scalia acknowledges that " $\mathrm{t}] \mathrm{o}$ be sure, the requirement that an agency provide reasoned explanation for its action would ordinarily

35. See Fox TV, Inc. v. FCC, 613 F.3d 317 (2d Cir. 2010); see also Christopher Hiserman, Silencing Fox: The Chilling Effect of the FCC's Indecent Speech Policy, 52 B.C. L. REV. E-SuPPLEMENT 15 (2011) (reviewing and defending the Second Circuit's decision), http://lawdigitalcommons.bc.edu/viewcontent.cgi?article=3193\&context=bclr/ [https://perma. cc/58TY-T4XE].

36. FCC v. Fox Television Stations, 556 U.S. 502, 514 (2009). 
demand that it display awareness that it is changing position." ${ }^{\text {37 }}$ Moreover, an agency must provide "a more detailed justification than what would suffice for a new policy created on a blank slate," in at least two sets of cases: (1) when "its new policy rests upon factual findings that contradict those which underlay its prior policy," and (2) "when its prior policy has engendered serious reliance interests that must be taken into account.",38

Justice Kennedy's concurrence expands on these two sets of cases where agency shifts call for searching review. He indicates that they cover more terrain of administrative law than Justice Scalia suggests. In doing so, Justice Kennedy suggests that State Farm and Fox are decisions woven from the same cloth. According to Justice Kennedy, "[W]hether a change in policy requires an agency to provide a more reasoned explanation than when the original policy was first announced is not susceptible, in my view, to an answer that applies in all cases." 39 In all cases of agency policy shifts, "[t]he question ... is whether the agency's reasons for the change, when viewed in light of the data available to it, and when informed by the experience and expertise of the agency, suffice to demonstrate that the new policy rests upon principles that are rational, neutral, and in accord with the agency's proper understanding of its authority." 40 Unless agencies are held to account for why a change in policy is reasonable in light of their expertise, "their actions might violate important constitutional principles of separation of powers and checks and balances." 41

Furthermore, Justice Kennedy's opinion specifically affirms that agencies must explain both why the data they relied upon in forming their old policy is no longer relevant and what new data supports the policy now proposed by the agency. The agency must explicitly address the facts and evidence that were available to and relied upon by the agency during the prior administration and the facts and evidence now available to and relied upon by the agency:

There may be instances when it becomes apparent to an agency that the reasons for a longstanding policy have been altered by discoveries in science, advances in technology, or by any of the other forces at work in a dynamic society. If an agency seeks to respond to new circumstances by modifying its earlier policy, the agency may have a substantial body of data and experience that can shape and inform the new rule. ... Where there is a policy change the record may be much more developed because the agency based its prior policy on factual findings. In that instance, an agency's decision to change course may be arbitrary and capricious if the agency ignores or countermands its earlier factual findings without reasoned explanation for doing so. An agency cannot simply disregard contrary or inconvenient

\footnotetext{
37. Id. at 515.

38. Id.

39. Id. at 535 (Kennedy, J., concurring).

40. Id. at 536 (Kennedy, J. concurring).

41. Id. (Kennedy, J. concurring).
} 
factual determinations that it made in the past, any more than it can ignore inconvenient facts when it writes on a blank slate. ${ }^{42}$

When compared to Justice Scalia’s majority opinion, Justice Kennedy's concurrence seems to provide more room for judges to apply a searching review with respect to the factual bases of changes in agency policy. (Still, even Justice Scalia acknowledges that an agency must explain its rationale for adopting a new policy that rests "upon factual findings that contradict those which underlay its prior policy." ${ }^{43}$ ) Justice Kennedy’s concurrence also strongly reaffirms State Farm and suggests that Fox in no way alters the kind of searching review called for in State Farm:

This is the principle followed in the Court's opinion in Motor Vehicle Mfrs. Assn. of United States, Inc. v. State Farm Mut. Automobile Ins. Co., 463 U.S. 29, 103 S. Ct. 2856, 77 L.Ed.2d 443 (1983). There, Congress directed the agency to issue regulations that would " "meet the need for motor vehicle safety."” ... The agency promulgated a regulation requiring cars to have passive-restraint systems-either airbags or automatic seatbelts. ... The agency based this regulation on its factual finding that these systems save lives. ..... Following a change in Presidential administration, however, the agency reversed course and rescinded the regulation. In doing so, the agency did not address its prior finding that airbags save lives. ... This Court found the agency's rescission arbitrary and capricious because the agency did not address its prior factual findings. 44

Justice Kennedy concurred rather than dissented in Fox, because he agreed with the majority that the FCC change in policy was based on a change in the agency's understanding of the First Amendment constraints imposed by Supreme Court case law, rather than any extra-legal facts. ${ }^{45}$ Justice Breyer's dissent calls this view into question, essentially making the same arguments as the Second Circuit had-namely, that the FCC had not accounted for the facts that justified its earlier policy or explained how those facts no longer applied. ${ }^{46}$ In Justice Breyer's view, State Farm compelled affirmance of

\footnotetext{
42. Id. at 535-37 (Kennedy, J. concurring).

43. Id. at 515 .

44. Id. at 537-38 (Kennedy, J. concurring).

45. Id. at 535 (Kennedy, J. concurring).

46. Id. at 564 (Breyer, J., dissenting) ("The FCC points to no empirical (or other) evidence to demonstrate that it previously understated the importance of avoiding the 'first blow.' Like the majority, I do not believe that an agency must always conduct full empirical studies of such matters. Ante, at 15-16. But the FCC could have referred to, and explained, relevant empirical studies that suggest the contrary. One review of the empirical evidence, for example, reports that '[i]t is doubtful that children under the age of 12 understand sexual language and innuendo; therefore it is unlikely that vulgarities have any negative effect.’ Kaye \& Sapolsky, Watch Your Mouth! An Analysis of Profanity Uttered
} 
the Second Circuit. But perhaps the most notable part of Justice Breyer's dissent was how it picked up on and clarified a theme found in both Justice Scalia's majority opinion and Justice Kennedy's concurrence- the theme of reliance interests and how agency shifts in policy must account for such interests in order to be deemed rational and compliant with the APA. ${ }^{47}$ Justice Breyer posed the following hypothetical to underscore his reliance interest point:

To explain a change requires more than setting forth reasons why the new policy is a good one. It also requires the agency to answer the question, "Why did you change?" And a rational answer to this question typically requires a more complete explanation than would prove satisfactory were change itself not at issue. An (imaginary) administrator explaining why he chose a policy that requires driving on the right side, rather than the left side, of the road might say, "Well, one side seemed as good as the other, so I flipped a coin.” But even assuming the rationality of that explanation for an initial choice, that explanation is not at all rational if offered to explain why the administrator changed driving practice, from right side to left side, 25 years later. 48

Justice Breyer's point seems to be that reliance interests may be large, indeed overwhelming, even if the initial agency policy was or now seems otherwise contestable. None of the opinions in Fox address how broadly reliance interests can be construed for purposes of understanding what an agency must take account of and explicitly address in shifting policy. None of the opinions suggest that reliance interests are necessarily limited to the entities directly regulated by the agency in question. In the real world, entities and individuals outside an agency's regulatory jurisdiction are affected by and rely upon agency policy. For example, building on Justice Breyer's hypothetical, a traffic official who decides that people should drive on the right side of the road may have no direct jurisdiction over car manufacturers, but those manufacturers will design their cars to work best in a right-side world if that is what traffic regulations have mandated. Similarly, EPA and NHTSA have no direct jurisdiction over entities that invest in the development of electronic batteries for cars or other fuel-economy-enhancing technology, but those entities are very much affected by the fuel economy standards promulgated by the agencies.

The relevance of reliance interests - and Fox as a basis for meaningful judicial review - are underscored by Justice Kennedy's opinion for the

by Children on Prime-Time Television, 2004 Mass CommuniCATION \& SoC’y 429, 433 (Vol. 7) (citing two studies). The Commission need not have accepted this conclusion. But its failure to discuss this or any other such evidence, while providing no empirical evidence at all that favors its position, must weaken the logical force of its conclusion.”).

47. Id. at 551-52 (Breyer, J., dissenting).

48. Id. at 549 (Breyer, J., dissenting). 
majority in Encino Motorcars. ${ }^{49}$ In that case, relying on Fox, the majority rejected an agency shift in position regarding which employees at automobile dealerships are entitled to overtime pay. Quoting extensively from Fox, the majority opinion faulted the Department of Labor for not taking into account reliance interest shaped by the prior Department of Labor policy. "In explaining its changed position, an agency must also be cognizant that longstanding policies may have 'engendered serious reliance interests that must be taken into account,' and 'a reasoned explanation is needed for disregarding facts and circumstances that underlay or were engendered by the prior policy.", 50

The circuit courts have applied Fox on a few occasions in exactly the way Justice Kennedy's concurrence says they should-to deem unlawful agency action where the agency has not provided a reasonable explanation as to why the facts underlying its previous policy are no longer valid. In Humane Society $v$ Locke, ${ }^{51}$ relying upon Fox, the Ninth Circuit held that the NMFS did not adequately explain its finding that sea lions had a "significant negative impact" on the recovery of listed salmonid populations given earlier factual findings by the NMFS that sea lions were not having a significant negative impact. ${ }^{52}$ In Organized Village of Kake, ${ }^{53}$ the Ninth Circuit addressed a reversal by the United States Department of Agriculture regarding application of the "Roadless Rule," limiting road construction and timber harvesting in national forests. In 2001, the Department expressly found that exempting the Tongass National Forest from this Rule "would risk the loss of important roadless area [ecological] values." ${ }^{4}$ Just two years later, relying on the factual record compiled in 2001, the Department reversed course, finding that the application of the roadless rule to the Tongass was "unnecessary to maintain the roadless values." 55 Relying heavily on Fox and Justice Kennedy's concurrence in particular, the Ninth Circuit found that the Department had failed to explain why its 2001 findings regarding ecological values no longer were true or mattered; the Department violated

\footnotetext{
49. 136 S. Ct. 2117, 2127 (2016) (citations omitted).

50. Id. at 2126.

51. Humane Soc’y of U.S. v. Locke, 626 F.3d 1040, 1051 (9th Cir. 2010).

52. Id. at 1048 .

53. Organized Vill. of Kake v. U.S. Dep’t of Agric., 795 F.3d 956, 970 (9th Cir. 2015).

54. Id. at 968 .

55. Id.
} 
the APA because it "did not address its prior factual findings" in a meaningful way. ${ }^{56}$

\section{THE CASE OF FUEL ECONOMY STANDARDS}

\section{A. Factual and Legal Background}

The Trump Administration's recent signal that it intends to revisit the issue of fuel economy standards offers a perfect case study of the dangers of deference in an age of hyper-polarization - and of the extent to which an agency can and should be bound by prior rulemakings. ${ }^{57}$ Of course, the Obama-era fuel economy standards were themselves the product of policy reversals - which highlights the difficulty of locating where to "begin" the analysis of any reversal-though these earlier reversals were arguably different in that they were attempts to inject science into a decision-making framework that had had been largely devoid of it. They were also, in part, an attempt to resolve a seemingly intractable dispute between those who wished to strengthen auto emissions standards under the Clean Air Act (CAA), and those who did not, and to harmonize the various regulatory proposals. ${ }^{58}$

This particular drama was the result of two important policy reversals in the early days of the Obama Administration. First, the Obama EPA issued a long-delayed "endangerment finding" under the CAA regarding greenhouse gas emissions. $^{59}$ This finding - the first step toward regulating greenhouse gases under the CAA — expressly referenced CAA Section 202(a) regarding mobile sources, ${ }^{60}$ setting the stage for EPA to regulate greenhouse gas emissions through setting auto mileage standards. ${ }^{61}$ The reversal, in this instance, stemmed from the fact that in the wake of the Supreme Court's decision in Massachusetts v. EPA, in which the Court chastised the EPA for refusing to make the finding and remanded to the agency to make such

56. Id. at 967 .

57. See Notice of Intention to Reconsider the Final Determination of the Mid-term Evaluation of Greenhouse Gas Emissions Standards for Model Year 2022-2025 Light Duty Vehicles, 82 Fed. Reg. 14,671 (Mar. 22, 2017) (40 C.F.R. pts. 523, 532, 533, 536 and 537).

58. See DANIEL SPERLING \& DEBORAH GORDON, TwO BILliOn CARS: Driving TOWARD SUSTAINABILITY 47 (2009).

59. See Endangerment and Cause or Contribute Findings for Greenhouse Gases Under Section 202(a) of the Clean Air Act; Final Rule, 74 Fed. Reg. 66,496 (Dec. 15, 2009) (40 C.F.R. pt. 1).

60. See id. at 66, 536.

61. As EPA later noted, there is no other way to regulate carbon dioxide emissions from cars other than through auto mileage standards. See Light- Duty Vehicle Greenhouse Gas Emission Standards and Corporate Average Fuel Economy Standards; Final Rule, 74 Fed. Reg. 24,007, 25,327 (May 22, 2009) (40 C.F.R. pts. 85, 86, and 600; 49 C.F.R. pts. 531, 533, 536, et al.). 
a finding unless it could justify a refusal based solely on the science, ${ }^{62}$ the Bush Administration refused to issue this same endangerment finding. ${ }^{63}$ The Bush Administration had taken the position that it would not issue an endangerment finding, not because of the science but because of the very economic and policy considerations that the Supreme Court had rejected. ${ }^{64}$

But before this refusal could be ruled upon through litigation, the Obama Administration came into office and reversed it. In December 2009, the Obama EPA issued a finding that greenhouse gases, including carbon dioxide, may reasonably be anticipated to endanger public health or welfare. ${ }^{65}$

The second major reversal had to do with granting California a waiver to enact its own auto emissions standards. In 2002, California passed legislation requiring the California Air Resources Board (CARB) to set greenhouse gas emission standards for vehicles. ${ }^{66}$ CARB's regulations setting such standards, however, required a waiver of preemption under the CAA, which generally preempts state regulation of new motor vehicle emissions standards but which also provides that California may obtain a waiver of such preemption as long as certain statutory criteria are met. ${ }^{67}$ California had made - and been granted - a number of waiver requests in the past. In fact, California had never been subject to an outright denial of a waiver request. ${ }^{68}$ But in 2008, after years of delay, the Bush Administration did just that-it denied California a waiver to regulate greenhouse gas emissions from motor vehicles. ${ }^{69}$

62. See Massachusetts v. EPA, 549 U.S. 497 (2007).

63. Id.

64. See Letter from Susan E. Dudley, Adm'r, Office of Info. \& Regulatory Affairs, to Stephen L. Johnson, Adm'r, EPA (July 10, 2008), http://www.reginfo.gov/public/ postreview/OIRA_letter_to_EPA_7_10_08.pdf) (stating that the EPA staff's draft rulemaking "cannot be considered Administration policy or representative of the views of the administration," and that "trying to address greenhouse gas emissions through the existing provisions of the Clean Air Act will not only harm the U.S. economy, but will fail to provide an effective response to the global challenge of climate change.").

65. See Endangerment and Cause or Contribute Findings for Greenhouse Gases Under Section 202(a) of the Clean Air Act; Final Rule, 74 Fed. Reg. 66,496, 66,497 (Dec. 15, 2009) (40 C.F.R. pt. 1).

66. See Cal. Health \& Safety Code § 42823, § 43018.5; See 42 U.S.C.S § 7507 (1990).

67. See 42 U.S.C.S. $\S 7543$ (1990). The CAA also provides that other states may choose to follow California's standards in lieu of federal standards.

68. GAO, Clean Air Act: Historical Information on EPA's Process for Reviewing California Waiver Requests and Making Waiver Determinations (Jan. 16, 2009), http:// www.gao.gov/assets/100/95940.pdf [https://perma.cc/QMC3-SBV7].

69. See supra note 68. 
The following year, however, the Obama Administration reversed course and granted this same waiver. ${ }^{70}$ The Obama EPA openly noted that it was rejecting the Bush-era interpretation of CAA Section 209(b)(1), stating that the waiver denial "was based on an inappropriate interpretation of the waiver provision." 71 While the Bush-era EPA had determined that "Congress intended to allow California to promulgate only those state standards that address pollution problems that are local or regional," and not global problems such as climate change, ${ }^{72}$ the Obama EPA stated that Congress "intentionally provided California the broadest possible discretion in adopting the kind of standards in its motor vehicle program that California determines are appropriate to address air pollution problems and protect the health and welfare of its citizens."73

In the wake of these two policy reversals, automakers faced a conundrum, with potentially conflicting California and federal regulation of auto mileage standards suddenly a distinct possibility. "Thus, as the Obama Administration came into office, the auto industry was facing at least two regulators, and probably three. And because of considerable potential for inconsistency in their respective approaches, the prospect of confusion and conflict was significant."74

In order to harmonize the various regulatory approaches, the Obama Administration engaged in a joint effort among federal and state officials, along with environmentalists and auto company representatives, to hammer out a "deal" that would be acceptable to all parties. ${ }^{75}$ The outlines of this deal have been thoroughly examined elsewhere; for our purposes, we will highlight a few salient aspects. ${ }^{76}$

First, EPA and NHTSA conducted a joint rulemaking, minimizing any conflict between federal agencies and harmonizing the various approaches (both technical and statutory) that each agency was accustomed to operating under. $^{77}$ The agencies also obtained non-binding "letters of commitment"

70. See Notice of Decision Granting a Waiver of Clean Air Act Preemption for California's 2009 and Subsequent Model Year Greenhouse Gas Emission Standards for New Vehicles, 74 Fed. Reg. 32,744, 32,745 (July 8, 2009).

71. Id. at 32, 746.

72. Id.

73. Id.

74. Jody Freeman, The Obama Administration's National Auto Policy: Lessons From the "Car Deal," 35 HARV. ENVTL. L. REV. 343, 353 (2011) (Freeman notes that, in addition to CARB and EPA, federal fuel mileage standards were also within the jurisdiction of the National Highway Transportation Safety Administration (NHTSA), under the Energy Policy and Conservation Act (EPCA), and that all three agencies "possessed substantial flexibility under their respective statutes.”).
75. Id.
76. Id. at $343,343$.
77. Id. at 361-62. 
from automakers agreeing in advance not to challenge the final rules. ${ }^{78}$ Perhaps most importantly, the agencies formalized California's commitment to the new standards in a unique way, by having the state agree to modify its regulations "to treat compliance with the new federal standards as equivalent to compliance with its own program." "79 California, like the automakers, used a "commitment letter" to memorialize its agreement based on certain explicit assumptions and understandings. ${ }^{80}$ Even so, a large part of what made this deal possible was mutual trust and a recognition that long-term certainty was in everyone's best interest. ${ }^{81}$

With the various stakeholders agreeing on the "deal" and agreeing not to challenge it in court, the Obama Administration was able to promulgate auto mileage standards that improved average required fuel economy from 27.6 miles per gallon in 2011 to 34.1 miles per gallon in $2016 .{ }^{82}$ But this was only "Phase 1 " of the overall fuel economy standards. ${ }^{83}$ Phase 2 covered Model Years 2017-2025. ${ }^{84}$ By the end, the standards "are projected to require, on an average industry fleet wide basis, 163 grams/mile of carbon dioxide (CO2) in model year 2025, which is equivalent to $54.5 \mathrm{mpg}$ if this level were achieved solely through improvements in fuel efficiency."

However, there was one small catch in the rule-an attempt at future flexibility that in hindsight seems less than wise. As part of its rulemaking for the 2017-2025 model years, EPA made a commitment to conduct a

78. Id. at 363 .

79. Id. at 365.

80. See letter from Mary Nichols to Lisa Jackson and Ray LaHood, available at https://www.epa.gov/sites/production/files/2016-10/documents/air-resources-board.pdf [https://perma.cc/GBB9-EHEK].

81. See Jody Freeman, The Obama Administration's National Auto Policy: Lessons From the "Car Deal,” 35 HARV. ENVTL. L. REV. 343, 369 (2011) (“All of this was done, not under a consent decree and with the imprimatur of the court in the context of litigation, but voluntarily. Thus the parties entered an agreement that is best described as a 'trust, but verify’ regime”); Obama unveils mpg rule, gets broad support, NBC NEWS (May 19, 2009) (quoting President Obama as saying that "this rule provides the clear certainty that will allow these companies to plan for a future in which they are building the cars of the 21st century").

82. See 75 Fed. Reg. 25,323, 25,330.

83. See Regulation for Greenhouse Gas Emissions from Passenger Cars and Trucks, United States ENVIRONMENTAL PROTECTION AgENCy (Nov. 17, 2016), https://www.epa.gov/ regulations-emissions-vehicles-and-engines/regulations-greenhouse-gas-emissionspassenger-cars-and [https://perma.cc/4AEX-W9LF].

84. Id.

85. See 2017 and Later Model Year Light-Duty Vehicle Greenhouse Gas Emissions and Corporate Average Fuel Economy Standards, 77 Fed. Reg. at 62,784. 
"Midterm Evaluation" (MTE) of the light-duty vehicle standards for model years 2022-2025, in coordination with NHTSA and CARB. ${ }^{86}$ At the time, the MTE was billed as a response to the long lead-time before the 20222025 standards were set to take effect. ${ }^{87}$ Formally, the MTE was designed to determine whether the light-duty standards for model years 2022-2025 were "appropriate under section 202(a)" of the CAA. ${ }^{88}$ The standards that were supposed to guide the MTE included a number of guiding factors. The regulation stated that the MTE "will be based on (1) A holistic assessment of all of the factors considered by the agencies in setting standards, including those set forth in the rule and other relevant factors, and (2) the expected impact of those factors on the manufacturers' ability to comply, without placing decisive weight on any particular factor or projection." ${ }^{89}$ The regulation also noted that "EPA would be legally bound to make a final decision, by April 1, 2018” regarding the MTE, but crucially, it gave no date before which the MTE could not be conducted. ${ }^{90}$

The regulation did go on to note that a number of factors, such as the development of powertrain improvements, the impact on employment in the auto sector, costs, and consumer acceptance of technologies, that would be used to inform EPA's determination. ${ }^{91}$ Once the EPA made its decision, moreover, that would be a final agency action subject to judicial review. ${ }^{92}$ The regulation also noted that "EPA will develop an administrative record for that review that will be no less robust than that developed for the initial determination to establish the standards. In the midterm evaluation, EPA will develop a robust record for judicial review that is the same kind of record that would be developed and before a court for judicial review of the adoption of standards." 93

There was some disagreement, as reflected in the regulation, over EPA's statutory authority to conduct the MTE. Chrysler had argued that the MTE was authorized by CAA section 307(d) and the Administrative Procedure Act on the ground that EPA could "reconsider regulations based on new information," while EPA disagreed that it was authorized by CAA section 307(d) because "the mid-term evaluation is not a reconsideration of the

86. White House Press Release, "President Obama Announces Historic 54.5 mpg Fuel Efficiency Standard” (July 29, 2011), https://obamawhitehouse.archives.gov/the-pressoffice/2011/07/29/president-obama-announces-historic-545-mpg-fuel-efficiency-standard [https://perma.cc/TJ59-EWFU].

87. See supra note 85 , at 62,784 .

88. See id. at 62,784 .

89. Id. at 62,784 .

90. Id.

91. Id.

92. Id.

93. Id. 
standards under that provision."94 Instead, EPA's position was that the MTE was authorized by "EPA's general authority to establish emissions standards under section 202(a)."95

In order to inform this decision and to prepare an appropriate record, EPA, NHTSA, and CARB had to jointly prepare a draft Technical Assessment Report (TAR) ${ }^{96}$ The agencies did just that, completing the Draft TAR on July 18, 2016. ${ }^{97}$ The TAR is an exhaustive 1,200 page document designed to assess the technologies available to meet the standards and two possible compliance pathways to meet those standards. ${ }^{98}$

The TAR concluded that "[a] wider range of technologies exist for manufacturers to use to meet the MY2022-2025 standards, and at costs that are similar or lower, than those projected in the 2012 rule." ${ }^{99}$ The TAR also concluded that:

- "Advanced gasoline vehicle technologies will continue to be the predominant technologies, with modest levels of strong hybridization and very low levels of full electrification (plugin vehicles) needed to meet the standards," and

- "The car/truck mix reflects updated consumer trends that are informed by a range of factors including economic growth, gasoline prices, and other macro-economic trends. However, as the standards were designed to yield improvements across the light duty vehicle fleet, irrespective of consumer choice, updated trends are fully accommodated by the footprintbased standards."

In other words, the TAR assumed that gasoline engines would continue to be the predominant engine form and also took into account updated consumer trends. Even so, the TAR saw no need to weaken the standards. The TAR also evaluated employment impacts, vehicle safety effects, and

\footnotetext{
94. Id. at 62,786 .

95. Id.

96. Id. at 62,784 .

97. NAT'L Highway TrafFic SAFETy Admin. (NHTSA), Light Duty CAFE Midterm Evaluation, https://www.nhtsa.gov/corporate-average-fuel-economy/light-duty-cafe-midtermevaluation [https://perma.cc/YQ7D-LQQQ].

98. Nat’l Highway Traffic Safety Admin., Cal. Air Resources Bd., EnvTL. Prot. AgENCy Draft TECHNICAL AsSESSMENT REPORT, at ES-2.

99. Id.

100. Id.
} 
alternative fuel infrastructure, and came to a similar conclusion. ${ }^{101}$ "Federal Agencies spent years conducting a rigorous 'midterm' review that included research by experts at EPA labs, technical analysis from experts across academia and input from a wide range of stakeholders, including automakers. This in-depth analysis show[ed], conclusively, that automakers can improve efficiency-and, thanks to technological innovation, they can do it at lower cost than federal agencies anticipated when these standards were developed."102

Yet automakers still balked, as gasoline prices were low and they were making considerable profits from light-duty vehicles. ${ }^{103}$ Then politics came into play, namely in the upcoming Presidential election. When, in November 2016, President Trump was unexpectedly elected, EPA moved up the timetable for making a final determination regarding auto mileage standards, even as automakers strenuously opposed "locking in" those standards. ${ }^{104}$ On January 12, 2017, shortly before Donald Trump would become President, the Obama EPA made a final determination that the 2022-2025 standards were indeed "appropriate" under the CAA. ${ }^{105}$

But this was not the end of the story. In February 2017, shortly after Trump took office, the chief executives of 18 automakers asked Trump to reopen the MTE process. ${ }^{106}$ A spokeswoman for the Alliance of Automobile Manufacturers claimed "the process was truncated" and that automakers were trying to "just restore the process." 107 The following month, Trump himself visited with auto executives and workers in Michigan, where he

101. Id. at ES-5.

102. See William K. Reilly \& Kenneth Kimmell, Automakers Shouldn't Fight Emissions Standards, N.Y. TimEs (Oct. 19, 2017), https:/www.nytimes.com/2017/10/19/opinion/ automakers-shouldnt-fight-emissions-standards.html [https://perma.cc/6TW2-K2JJ].

103. Adele Peters, Automakers Say They're Going Electric-But They're Also Lobbying for Weaker Fuel Standards, FAST COMPANY (Nov. 17, 2017), https://www.fastcompany. com/40497293/automakers-say-theyre-going-electric-but-theyre-also-lobbying-forweaker-fuel-standards [https://perma.cc/86LD-EEFB]; see also Chester Dawson, Gas Prices Take a Backseat for Auto Makers, WALL ST. J. (Jan. 10, 2017), https://www.wsj.com/articles/ gas-prices-take-a-backseat-for-auto-makers-1484044201 [https://perma.cc/PQB3-UQJG].

104. See David Shepardson, EPA Locks in 2025 Fuel Efficiency Rules, REUTERS (Jan. 13, 2017), http://www.reuters.com/article/us-usa-automakers-idUSKBN14X1Q6 [https://perma. cc/HVT2-N3XU].

105. See Letter from Gina McCarthy to Stakeholders, EnVTL. Prot. Agency (Jan. 12, 2017), https://www.epa.gov/sites/production/files/2017-01/documents/mte-stakeholderletter-2017-01-12.pdf [https://perma.cc/95G2-SAXG]. See also Final Determination on the Appropriateness of the Model Year 2022-2025 Light-Duty Vehicle Greenhouse Gas Emission Standards Under the Midterm Election, ENVTL. PRot. AgENCY 1, 29 (2017), https://nepis.epa.gov/Exe/ZyPDF.cgi?Dockey=P100QQ91.pdf [https://perma.cc/K66R-7U9J].

106. See Ryan Beene, Auto CEOs Ask Trump to Revisit Obama-era Fuel Efficiency Rules, BLOOMBERG (Feb. 11, 2017), https://www.bloomberg.com/news/articles/2017-02-11/ auto-ceos-ask-trump-to-revisit-obama-era-fuel-efficiency-rules [https://perma.cc/7769-6BND].

107. Id. 
announced his own determination that the MTE should be reconsidered. ${ }^{108}$ Trump claimed at that event that he would encourage growth in the U.S. Auto sector and that "[t]he assault on the American auto industry is over."109 Then on March 22, 2017, the EPA under the Trump administration published a "Notice of Intention to Reconsider the Final Determination of the MidTerm Evaluation of Greenhouse Gas Emissions Standards for Model Year 2022-2025 Light Duty Vehicles." ${ }^{\text {"110 }}$ The EPA claimed in this notice that it had "inherent authority to reconsider past decisions," citing FCC v. Fox to support its position. ${ }^{111}$ In other words, Scott Pruitt, the EPA administrator, signaled that the EPA was "ready to ignore years of scientific and economic analyses that underpinned the agency's decision" in the MTE that standards should remain in place. ${ }^{112}$

\section{B. Possible Avenues of Litigation}

Assuming that the EPA reverses course and uses the new MTE process to weaken mileage standards, then the question becomes what the court's challenge to this reversal will look like and what standard of review the court will apply. There will certainly be serious questions about whether the EPA lacks a regulatory or statutory basis for revisiting the MTE. However, for purposes of this paper, we will focus on the factual challenges, namely whether any new rulemaking conducted pursuant to the EPA revisiting the MTE violates the APA, and whether it meaningfully addresses the facts that the EPA relied on when it issued its final decision.

First, the EPA will likely claim that it has "inherent authority to reconsider past decisions" and that such authority alone is sufficient to justify revisiting the MTE. ${ }^{113}$ However, the EPA will probably lose this argument. Recently, the EPA made a similar claim that it has "inherent authority" to stay

108. See John Lippert et al., Trump to Meet with Auto Leaders, Workers in Michigan Visit, CRAIN’s DETROIT Bus. (Mar. 13, 2017), http://www.crainsdetroit.com/article/20170 313/NEWS01/170319950/trump-to-meet-with-auto-leaders-workers-in-michigan-visit [https://perma.cc/WCJ9-AMCH].

109. See Nick Carey \& David Shepardson, Big Win for Automakers as Trump Orders Fuel Economy Standards Review, REUTERS (Mar. 15, 2017), http://www.reuters.com/ article/us-usa-trump-autos-idUSKBN16M2C5 [https://perma.cc/ZM23-4H43].

110. 82 Fed. Reg. 14,671-01, 14,671 (proposed Mar. 22, 2017).

111. Id.

112. William K. Reilly et. al., Automakers Shouldn't Fight Emissions Standards, N.Y. TIMES (Oct. 19, 2017), https://www.nytimes.com/2017/10/19/opinion/automakersshouldnt-fight-emissions-standards.html?_r=0 [https://perma.cc/E2US-DBVB].

113. 82 Fed. Reg. at 14,671 . 
the Obama-era methane rule-a claim that the D.C. Circuit shot down by noting that it is "axiomatic" that "administrative agencies may act only pursuant to authority delegated to them by Congress," and that the statute hadn't given the EPA the power to issue such a stay. ${ }^{114}$

Thus, the EPA will have to grapple with the facts. The EPA will likely argue that the regulation contemplates a "holistic" review process and that this allows a wide range of factual justifications for revisiting the MTE. ${ }^{115}$ However, the problem here is that the EPA has identified no factual or procedural defect with the original MTE decision. Instead, the EPA stated that "[i]n 2012, EPA committed to continuing to coordinate development of its Clean Air Act (CAA) section 202(a)(1) (42 U.S.C. 7521(a)) emission standards with NHTSA's development of CAFE standards for light-duty vehicles, but did not do so in development and publication of EPA's January 12, 2017 Midterm Evaluation." 116 It is unclear whether this statement is sufficient to justify revisiting the MTE. While the 2012 regulation does contemplate that "EPA and NHTSA will finalize their actions related to MYs 2022-2025 standards concurrently," ${ }^{117}$ there appears to be no requirement that the EPA withhold its MTE until NHTSA has finalized its own CAFE standards. The 2012 regulation also stated that "EPA, NHTSA and CARB will jointly prepare a draft Technical Assessment Report (TAR) to inform the EPA's determination on the appropriateness of the GHG standards and to inform NHTSA's rulemaking for the CAFE standards for MY 20222025" and that the "EPA and NHTSA will consult and coordinate in developing EPA's determination on whether the MY2022-2025 GHG standards are appropriate under section 202(a) and NHTSA's NPRM.”118

The problem for EPA is that EPA and NHTSA did jointly prepare the TAR and did consult and coordinate in developing EPA's determination whether the standards were appropriate. NHTSA was involved in drafting the TAR itself-Chapter 13 of which presents NHTSA's detailed technical support for the rule-and expressly used its CAFE model to support its and EPA's results. ${ }^{119}$ Moreover, as noted supra, nowhere did EPA state that it had to wait until NHTSA came up with separate CAFE standards before it made its own MTE determination. While EPA now says that NHTSA's

114. Clean Air Council v. Pruitt, 862 F.3d 1, 12 (D.C. Cir. 2017).

115. 77 Fed. Reg. 62,624, 62,784 (Oct. 15, 2012) (The MTE “will be based on (1) A holistic assessment of all of the factors considered by the agencies in setting standards, including those set forth in the rule and other relevant factors, and (2) the expected impact of those factors on the manufacturers' ability to comply, without placing decisive weight on any particular factor or projection.").

116. 82 Fed. Reg. at 14,671.

117. 77 Fed. Reg. at 62,784.

118. Id.

119. See Draft TAR, at 13-1. 
CAFE standards would be "appropriate" for it to consider, ${ }^{120}$ the risk is that this standard is far too broad to support any kind of judicial review, and comes perilously close to the agency claiming it has "inherent authority" to revisit its rules, a claim that courts have rejected, as we note supra. ${ }^{121}$ Moreover, a court may also decide that EPA's broad claim that it can revisit past decisions whenever "appropriate" provides no meaningful basis for judicial review because it provides no justiciable metric by which to decide whether such an action comports with the APA. On this basis alone, a court may decide that EPA has exceeded its authority by revisiting the MTE.

A related challenge is that EPA will have to provide an adequate factual basis for revisiting the MTE under an entirely new rulemaking. This is contemplated in the regulation itself, which states that EPA "will initiate a rulemaking" if it determines that the standards are not appropriate. It is also contemplated by the courts, which have made it clear that agencies must "use the same procedures when they amend or repeal a rule as they used to issue the rule in the first instance."122

This new rulemaking will presumably have to explain why the facts laid out in the TAR are wrong and why the agency is reversing course in order to meaningfully address its prior factual findings. Here, the degree of scrutiny that a court will apply can prove decisive. As explained supra, a court may be justified in conducting a searching review of the extent to which the agency addresses what it did before-and the agency's stated rationales-given the risk that politics has undermined the agency's scientific and factual predicates for rulemaking. This is especially true because the Clean Air Act is an essentially science-driven statute, and the EPA is supposed to be guided by science when making its decisions. ${ }^{123}$

120. See 82 Fed. Reg. 54 (Mar. 22, 2017), citing 40 CFR 86.1818-12(h)(1)(vii) (listing as one of the factors EPA should consider in the Mid-Term Evaluation "[t]he impact of the greenhouse gas emission standards on the Corporate Average Fuel Economy standards and a national harmonized program").

121. In other words, if the agency may reopen a prior decision anytime it feels it is "appropriate" to do so, there would be no limit to such revisions, making this claim indistinguishable from the claim that the agency has "inherent authority" to revisit past decisions.

122. Perez v. Mortg. Bankers Ass’n, 135 S. Ct. 1199, 1206 (2015); Clean Air Council, 862 F.3d at 9 .

123. See generally Massachusetts v. EPA, 549 U.S. 497 (2007); see also Coal. for Responsible Regulation v. EPA, 684 F.3d 102 (D.C. Cir. 2012) (upholding a quartet of EPA's CAA's rules, including its endangerment finding). 
Thus, a court will face the serious issue of whether EPA's statementabout revisiting the MTE because NHTSA hadn't yet set a maximum feasible CAFE standard-is a mere pretext for an essentially political decision and is designed to circumvent the factors in the statute and regulation that were supposed to guide its decision. This is especially true if NHTSA suddenly claims that the "maximum feasible" CAFE standard requires a weakening of the standards that it said, just a few months before, were not only feasible but desirable as well, and if EPA similarly claims that the "appropriate" emissions standards are less stringent than what it recently claimed.

\section{OBJECTIONS AND COUNTERARGUMENTS}

With the preceding in mind, it is useful to explore the possible objections to a searching, hard look review of agency shifts in position following elections. Such objections include: (1) such review will cause more nonideological mistakes by judges due to their lack of technical expertise, and (2) such review will worsen partisanship and ideological excess by freeing ideologically-driven judges to override policy shifts based on their own preferences (i.e., Republican judges will strike down agency policies after a Democratic President is elected and vice versa). We do not take either objection lightly but argue that, overall, the benefits of searching review, especially ex ante on agency policy formation prior to any judicial challenge, outweigh possible costs in our current era of hyper-polarization. These objections, however, do underscore the importance of preserving key institutional protections against hyper-polarization and its harmful effects - the rating of appointees by the American Bar Association, Senate confirmation only after a hearing, and the political taboo against courtexpansion and court-packing schemes for partisan reasons. ${ }^{124}$ These institutional features help assure that any shifts in the partisan affiliations of the judiciary occur gradually, relative to the sharp shifts that can occur every two and four years in the other branches of government.

124. The strongly negative reaction across the political spectrum to a recent proposal by Professor Calebresi that the Republican Congress radically expands the number of federal judges so that President Trump can secure a majority of Republican appointees in every Court of Appeals suggest that this taboo, thankfully, still has force. Linda Greenhouse, $A$ Conservative Plan to Weaponize the Federal Courts, N.Y. Times (Nov. 23, 2017), https:// www.nytimes.com/2017/11/23/opinion/conservatives-weaponize-federal-courts.html?_r=0 [https://perma.cc/97UF-RMK3]; William H. Pryor, Jr., Conservatives Should Oppose Expanding the Federal Courts, N.Y. Times (Nov. 29, 2017), https://www.nytimes.com/ 2017/11/29/opinion/conservatives-expanding-federal-courts.html [https://perma.cc/83Q7UW4V]. 
As a preliminary matter, one needs to acknowledge that formal standards of review - whatever they are-may matter less than administrative law scholars and commentators might believe. There is some empirical work that suggests a lack of relationship between standard of review and how often agency action is upheld. ${ }^{125}$ But the vigor with which standards of review are debated provides some evidence that the people closest to and with the greatest knowledge of administrative law think they do matter, and that in itself suggests they may. ${ }^{126}$ Moreover, our argument is that, whatever judges call their standard of review, they should apply a searching one in response to polarization and its effects on agency determinations.

With respect to the non-ideological mistakes point, our main rejoinder is that judges review what agencies say as to why they acted as they did. Agencies thus can explain that they are relying on their expertise and if they genuinely are relying on expertise, they can provide cogent explanations, ideally backed up by external experts without a direct pecuniary stake in the issue at hand. If (to respond to Vermeule's and Gerson's argument) there are genuine factual uncertainties, it is better for an agency to explain those uncertainties and insist that in the face of those uncertainties they are entitled to choose how to proceed. We do not see how it can be better for agencies to deny uncertainties and claim a certitude the factual record simply cannot support.

125. See Richard J. Pierce, Jr. \& Joshua Weiss, An Empirical Study of Judicial Review of Agency Interpretations of Agency Rules, 63 ADmin. L. REV. 515, 515 (2011) ("With one exception, the studies found that a court's choice among six review doctrines had little, if any, effect on the outcome of cases. Courts at all levels of the federal judiciary uphold agency actions in about $70 \%$ of cases, no matter whether the court applies Chevron, Skidmore, State Farm, Universal Camera, or de novo review.”); Richard J. Pierce, Jr., What Do the Studies of Judicial Review of Agency Actions Mean?, 63 ADMIN. L. REV. 77, 85 (2011) ("With one notable exception, the studies suggest that a court's choice of which doctrine to apply in reviewing an agency action is not an important determinant of outcomes in the Supreme Court or the circuit courts.”); David Zaring, Reasonable Agencies, 96 VA. L. REV. 135, 137 (2010) ("The outcomes of actual cases prove the point: whether the question is one of fact, law, or arbitrariness, whether the agency procedures were formal or informal, whether judicial deference is required or not, the courts - even though in theory they would apply different degrees of scrutiny to each of these questions - reverse agencies slightly less than one third of the time.”). The literature also confirms that courts uphold agency action in the great majority of cases, regardless of the applicable standard of review. Pierce \& Weiss, supra, at 515; Pierce, supra, at 83; Zaring, supra, at 137.

126. See Levin, supra note 12, at 555-56. 
As a matter of prevailing legal culture, and for institutional reasons, judges are inclined to defer if faced with a plausible technical argument for deference. Judges and legal commentators now primarily debate what deference is due with respect to questions of statutory and regulatory interpretation, ${ }^{127}$ precisely because, we would argue, deference on factual/ technical determinations is so accepted in our legal culture. Moreover, deference on factual/technical determinations is simply easier for judges than wading into a subject matter terrain with respect to which they lack professional credentials and training and explaining why they see insufficient grounds for deferring. Given all that, the greater risk (putting judicial partisanship aside) is that judges will defer based on almost nothing rather than that they will override a reasoned, expertise-grounded, fact-based explanation provided by an agency.

But of course judges do not judge free from ideology or, in particular, ideology associated with partisanship. Judges are part of the culture of political polarization in the United States at large. ${ }^{128}$ Also, the judicial selection process has become more partisan and arguably has resulted in the appointment of more partisan judges. ${ }^{129}$ Yet there are forces that temper

127. See, e.g., Bradley George Hubbard, Deference to Agency Statutory Interpretations First Advanced in Litigation? The "Chevron" Two-step and the "Skidmore" Shuffle, 80 U. CHI. L. ReV. 447 (2013); Kristin E. Hickman, The Three Phases of Mead, 83 FordHam L. ReV. 527 (2014-2015); William N. Eskridge Jr., Chevron as a Canon, Not a Precedent: An Empirical Study of What Motivates Justices in Agency Deference Cases, 110 ColUMBIA L. REV. 1727 (2010); Stephen M. Johnson, Advancing Auer in an Era of Retreat, 41 WM. \& MARY L. \& POL'Y REV. 551 (2016-2017).

128. See Dan Kahan et al., Comment, Ideology or Situation Sense: An Experimental Investigation of Motivated Reasoning and Professional Judgment, 164 U. PA. L. REV. 349, 352-53 (2016) ("The evidence, according to experts, vindicates the public's impression that judges (despite their own protestations) are just 'junior varsity politicians”'); see also Richard E. Redding \& N. Dickson Reppucci, Effects of Lawyers' Socio-Political Attitudes on the Judgment of Social Science in Legal Decisionmaking, 23 L. \& HuM. BEHAV. 31 (1999) (finding support for the view that ideology or attitudes influence judicial decisions regarding empirical issues); see also RichARD A. POSNER, How Judges THINK 116 (Harv. Univ. Press 2008) (assessing that cultural orientation influences judicial assessments of empirical evidence).

129. See generally David Leonhardt, How to End the Politicization of the Courts, N.Y. Times (Apr. 4, 2017), https://www.nytimes.com/2017/04/04/opinion/how-to-end-thepoliticization-of-the-courts.html [https://perma.cc/7R5L-62N2]; James Robertson, The Judicial Nomination War Started with Bork. Let's End it with Gorsuch, WAsH. Post (Mar. 15, 2017), https://www.washingtonpost.com/opinions/the-judicial-nomination-war-started-withbork-lets-end-it-with-gorsuch/2017/03/15/3effeb4e-0990-11e7-b77c-0047d15a24e0_story. html?utm_term=.bb4733211702 [https://perma.cc/9KGW-JCPZ; Nina Totenberg, Robert Bork's Supreme Court Nomination 'Changed Everything, Maybe Forever,' NPR (Dec. 19, 2012), http://www.npr.org/sections/itsallpolitics/2012/12/19/167645600/robert-borks-supremecourt-nomination-changed-everything-maybe-forever [https://perma.cc/BR54-65JF]; John M. Walker Jr., The Unfortunate Politicization of Judicial Confirmation Hearings, THE ATLANTIC (July 9, 2012), https://www.theatlantic.com/national/archive/2012/07/the-unfortunatepoliticization-of-judicial-confirmation-hearings/259445/ [https://perma.cc/J24N-YDN7]. 
partisanship in the judging of agency action. Agency rules are reviewed directly by a Court of Appeals, and there often will be some diversity in political affiliations among the relevant judges in three-judge panels and (where granted) en banc panels. Where a panel has a judge appointed by both a Republican President and a Democrat one, there is some evidence that the role of partisanship in decisions is substantially tempered, as compared to panels where all judges are affiliated with the same party. Panel diversity checks, if imperfectly, the distortions of political polarization. ${ }^{130}$

Of course, an agency may draw an unusually favorable panel, but, crucially, agencies do not know the partisan make-up of the panel they will draw when a rule or other action ultimately is reviewed by a court. Operating ex ante, and in a regime where policy shifts do receive a hard look, agency actors, especially if risk averse, presumably will try to go about formulating policy and assembling records that do take account of and address available facts, including those more often relied upon by members of the "other" political party and in particular those relied upon by the previous administration. We thus would assume that, where we see agency shifts after elections, they will be at least somewhat more grounded factually under a regime of searching review than under one without such review.

Moreover, even in these partisan times, and even when certain Circuits have become heavily dominated by judges thought to be affiliated with one political party, judges' training as lawyers and role-identification as neutral authorities may lead them to act in a more objective, less ideologicallypolarized fashion than Executive branch personnel and the party activists and donors who impose pressure on them. To take one recent example, appellate judges appointed by Republican Presidents joined ones appointed by Democratic Presidents in faulting a Trump Executive Order banning entrants into the United States from certain predominantly Muslim nations, on the grounds that the ban was not based on credible factual suppositions. ${ }^{131}$

130. See Cass R. Sunstein \& Thomas J. Miles, Depoliticizing Administrative Law, 58 DUKE L.J. 2193, 2197-98 (2009) (suggesting that mandatory mixed panels are the best, but not readily achievable, solution to politicization and reviewing the evidence regarding panel composition effects, the bulk of which suggests the benefits of having at least one judge appointed by a Democrat and a Republican on every panel). See also Thomas J. Miles \& Cass R. Sunstein, Do Judges Make Regulatory Policy? An Empirical Investigation of Chevron, 73 U. CHI. L. REv. 823 (2006); Kevin M. Quinn, The Academic Study of Decisionmaking on Multimember Courts, 100 CAL. L. REV. 1493 (2012); Emerson H. Tiller, The Law and Positive Political Theory of Panel Effects, 44 J. OF LEGAL STUD. S1, S35-S58 (Jan. 2015).

131. See International Refugee Assistance Project v. Trump, 857 F.3d 554, 592 (4th Cir. 2017) ("Based on this evidence, we find that Plaintiffs have more than plausibly alleged 
Experimental research by Daniel Kahan and others provides some support for what we observed in the Fourth Circuit. This research suggests that lawyers and judges, regardless of where they fall on a polarization scale, reach more grounded, less ideological decisions on questions of statutory construction than non-lawyers. Kahan and his colleagues postulate that "[i]t is thus possible that the professional judgment of the judge, as an expert neutral decisionmaker, embodies exactly the form of information processing most likely to counteract identity-protective reasoning" that lead others to rely on what might be termed "alternative facts." 132 Lawyers and judges "reliably fix their attention on pertinent elements of case 'situation types,' thereby immunizing them from the distorting influence that identityprotective cognition exerts on the judgments of legally untrained members of the public.",133

Another possible objection to our approach is that it would not make policymaking any less inconsistent, but simply incentivize agencies to ground their policy shifts in normative claims — values or ideology-rather than factual ones. ${ }^{134}$ For example, the Trump Administration could seek to justify laxer fuel economy standards in a rulemaking on the explicit grounds that any loss in environmental benefits is simply less important than avoiding short-term economic burdens on automobile makers, even though the previous standards concededly could be met without any greater costs than the

that EO-2's stated national security interest was provided in bad faith, as a pretext for its religious purpose. And having concluded that the "facially legitimate" reason proffered by the government is not "bona fide," we no longer defer to that reason and instead may "look behind” EO-2.”) (opinion joined by all Republican and Democratic-appointed judges).

132. See Dan M. Kahan et. al., "Ideology” or "Situation Sense?” An Experimental Investigation of Motivated Reasoning and Professional Judgment, 64 U. PA. L. REV. 349, 375 (2016).

133. Id. at 375. There are to be sure limits in the Kahan et al. analysis: most notably, it brackets the question of the role of ideology in actually litigated cases on the grounds that those are the cases where ideological differences most come into play, but those are precisely the cases of greatest interest in assessing the impact of ideology. See id. at 358-63. Moreover, as the authors acknowledge, the scope of the experimental study is necessarily limited. See also Larsen, supra note 10 (discussing possible relevance of the Kahan et al. experimental work regarding judges).

134. Nat'l Ass'n of Home Builders v. E.P.A., 682 F.3d 1032, 1038 (D.C. Cir. 2012), is one example of an agency changing policy based on its having a different normative assessment of competing considerations than the agency during the previous administration. In that case, the D.C. Circuit affirmed an agency rule that eliminated an "opt-out" provision that exempted certain owner-occupied housing from a rule regulating renovation and remodeling activities that created health hazards arising from lead paint. As the Court explained, "the petitioners are correct: EPA did not rely on new facts, but rather on a reevaluation of which policy would be better in light of the facts.” The Court concluded that because EPA acted transparently and did not purport to rely on factual expertise but rather openly re-evaluated its policy based on a higher valuation of human life and health, Fox did not require the agency to "explain away" previous factual records. 
previous administration estimated. Whether such a strategy would work would depend on the court's answer to the legal question of whether the applicable statute and regulations (including the APA) allow agencies the discretion to shift policy based on that sort of justification. ${ }^{135}$

More honest, transparent statements of the values driving agency policy shifts could enhance public debate and democratic discourse, at least if the courts are able to sort between values "puffery" and genuine, cogent valuesbased rationales. In sum, genuinely hard look review may produce either more factually-grounded agency decisions (including, sometimes, the decision not to shift policy after an election) or more transparently value-driven ones, both of which may be preferable to agency decisions ostensibly rooted in, but poorly supported by, the range of facts available to the agencies.

\section{CONCLUSION}

Agency policy shifts do not occur in a political or cultural vacuum. In our current age of hyper-polarization and alternative facts, the case for robust judicial deference to agency's invocation of technocratic expertise is weakened, but by no means negated, when an agency changes course after the election of a President from a different party than his or her predecessor. Rather, because it is both true that agencies have distinctive expertise judges lack and hyper-polarization necessarily calls into question the good faith of agency invocations of technical expertise as a rationale for policy shifts, the federal courts should require agencies to identify and explain the available factual evidence and, in particular, to meaningfully account for the factual evidence known to and factual record relied upon by previous administrations. Supreme Court precedent allows and indeed compels courts to do just that, notwithstanding how Fox has been read by some commentators. For their part, legislators and regulators who want fact-based government administration can and should facilitate meaningful judicial review of agency policy shifts by drafting laws and regulation that require agencies to tie policy reviews and adjustments to relevant factual determinations

135. See State Farm, 463 U.S. at 59 (Rehnquist, J., dissenting) (“A change in administration brought about by the people casting their votes is a perfectly reasonable basis for an agency's reappraisal of its programs and regulations. As long as the agency remains within bounds established by Congress, it is entitled to assess administrative records and evaluate priorities in light of the philosophy of the administration.”). As noted above, it also would be relevant whether the agency's values rationale was sufficiently detailed, specific and consistent so as to warrant being credited as a good faith rationale amenable to genuine judicial review. See supra note 17. 
and redeterminations. The courts cannot be expected to be free from hyperpolarization or to be its sole remedy, but they can play a very important part in mitigating the negative effects of hyperpolarization on the administrative state. 